\title{
ANNALS
}

OF

\section{The Entomological Society of America}

\section{THE DEVELOPMENT OF ENTOMOLOGY IN Instifuto, NORTH AMERICA.*}

\author{
By W. J. Holland.
}

The other day in one of the large astronomical observatories of our country the Director showed me some of the plates, which they are making in collaboration with other observatories, which have united to systematically photograph the whole of the sidereal expanse. The plates showed innumerable little white dots on a black background. The largest of these dots were not bigger than a small fly-speck. "How many suns are there?" I asked. "There are only about five thousand visible to the naked eye in both hemispheres," replied the astronomer, "but with the help of our improved telescopes, reinforced by photography, it is estimated that we can now locate about two millions of suns." "Just about the number of the species of insects, with which we entomologists have to deal," I answered, "arid we have the advantage of being able to get at them and dissect them, and learn all about them, while you at the utmost can only learn a little about these stars."

\section{"Natura maxime miranda in minimis,"}

But my theme this evening is not the vastness of the field of entomological research. When I was requested to address you, I chose as my subject the development of our science in North America.

The first studies of the insect-life of the New World were made by Europeans. We must not overlook the writings of the Spanish chroniclers, in whose pages we occasionally find ref-

* Annual address delivered before the Entomological Society of America, St. Louis, Missouri, December 30, 1919. 
erences to the insects of the newly discovered lands. Oviedo as early as 1526 alludes to the abundant and torturing insect pests of the regions which he visited. At a later date-Catesby and Sir Hans Sloane attempted an account of some of the species encountered in the Carolinas and the West Indies. Then came the immortal Linnæus and his disciple, Charles Clerck, who about one hundred and sixty years ago began to lay substantial foundations by naming, describing, classifying, and figuring many North American insects. Some of the remnants of the Linnæan Collection are still preserved at Upsala in Sweden, where I had the pleasure a few years ago of examining what is left of them.

Linnæus possessed an encyclopedic mind. His Systema Naturce was a bold attempt to classify all the living organisms of which he had knowledge from the greatest to the smallest. No one of the sciences now comprehended under the great and inclusive term entomology but recognizes his influence. All students who make a study of the various orders of insects recognize that the Sage of Upsala was the first to blaze the way into fields, which, as the years have gone by, have seemed ever to expand, and to be more and more filled with wonders.

In the last two decades of the eighteenth and in the early years of the nineteenth century a number of Europeans amplified and extended the labors of Linnæus. The student of North American entomology recognizes his debt to Fabricius, whose writings must still be consulted by systematists. About this time Cramer issued his great work upon the lepidoptera exotic to Europe, the fourth and last volume appearing in 1782, being supplemented by Stoll, whose work appeared from 1787-1791, and who also published important works upon the hemiptera, homoptera, and orthoptera, which the student of today cannot neglect. Smith and Abbot's "Natural History of the Rarer Lepidopterous Insects of Georgia," issued in two folio volumes in 1797, is one of the monumental works of this period. It must always be occasion for regret that the original drawings made by Abbot of the insects belonging to other orders which he depicted, the originals of which are preserved in the British Museum, were not published. Abbot was a careful observer and an accomplished draftsman, whose work deserved a better fate than to be simply buried in the portfolios where they still may be seen. To this period also belong the writings of Latreille, 
and others of the enclycopedists, who collaborated with him, notably A. G. Olivier.

A work of great beauty for the times, which began to appear in 1806, is Hübner's Exotische Schmetterlinge. It continued to be issued until 1824, and was supplemented from 1818-1832 by Carl Geyer. In this quite a considerable number of North American lepidoptera are represented for the first time by recognizable figures. We also must not forget the writings of Palisot de Beauvois.

The earliest paper written by a native of America upon an entomological theme to which I have been able to find reference is an article by John Bartram, who was born in 1701 in Pennsylvania, and who in the Philosophical Transactions, published in London in 1745, gives "An Account of Some Very Curious Wasp-Nests of Clay in Pennsylvania," accompanied by a figure. He subsequently contributed several other brief entomological papers to the same journal. Moses Bartram, his son, in 1766 wrote an article entitled, "Observations on the Cicada or Locust of America, which Appears Periodically Once in 16 or 17 Years." This was published in 1767 in the Annual Register, the editor of which states that the paper had been "communicated by the ingenious Peter Collinson." The name of Collinson is perpetuated in the genus Collinsonia, one of the Labiatce. Collinson aided Linnæus, the author of the genus, by sending him collections of exotic plants.

The real beginning of an indigenous literature dealing in a truly scientific manner with entomological subjects is found in the writings of Thomas Say, the Patron Saint of our Society, who was born in Philadelphia in 1787, the year in which the Northwest Territory was organized by the Congress of the Thirteen States, and in which the General Assembly of Pennsylvania granted the first charter for an institution of learning west of the Allegheny Mountains to the school, which is now the University of Pittsburgh. Thomas Say was one of the founders of the Academy of Natural Sciences in Philadelphia, which celebrated its centennial in 1912. The first paper from his pen, dealing with entomology, was entitled "Description of Several New Species of North American Insects." It appeared in the Journal of the Academy in June, 1817, being pages 19-23 of the First Volume of that important publication. 
Only two years more than a century have elapsed since this first article upon entomology from the pen of Thomas Say was published. In this century there has occurred upon American soil an enormous extension of entomological research. The century must, however, be divided for our purposes into two epochs, one preceding the great Civil War, the other following it.

The epoch preceding the Civil War was far less fruitful than that which succeeded it. An examination shows that prior to 1865 the number of laborers in the field was small, and that among those engaged in studying North American insects European students and writers still outnumbered those upon the soil of the New World. The publications of native Americans, though valuable, were not numerous. The economic importance of entomology was not generally recognized. The impulse toward biological research, which arose after the announcement of the doctrines of Darwin, Wallace, and their fellow-laborers, had not yet been felt.

The principal repositories of entomological information in North America during the first half of the nineteenth century are periodicals which were issued by a limited number of learned societies. The Academy of Natural Sciences in Philadelphia led the way with its Proceedings. The American Philosophical Society, which had been founded earlier than the Academy of Natural Sciences, became the sponsor in its Transactions for a number of papers written by Thomas Say, the first being "A Monograph of the Genus Cicindela," which was followed by others. Both of these publications became favorite media for the followers of Say in which to announce their discoveries, and the results of their studies. In 1834 The Boston Society of Natural History was formed. Among its earliest publications were two papers, one upon "North American Coleoptera," the other upon the "Hymenoptera of America," written by Say, but which did not appear until some time after his death. In addition to these publications I may mention "The Annals of the New York Academy of Sciences," numbering thirteen volumes, beginning in 1819, and thereafter continued at irregular intervals; "The Annals of the Lyceum of Natural History of New York," the series extending from 1824 to 1877 ; the "American Journal of Science and Arts," often spoken of as "Silliman's Journal," the entomological content of which is relatively small, though important; "The Proceedings 
of the California Academy of Natural Sciences," which began to appear in 1854. The first series of this latter journal consists of seven volumes, in which there are a number of valuable papers upon entomological subjects from the pens of Dr. Herman Behr, Henry Edwards, and others. It is a set of books now hard to get, as the greater part of the volumes were burned in a fire. In 1848 the Smithsonian Institution began to publish, and in the "Smithsonian Miscellaneous Collections," and the "Smithsonian Contributions to Knowledge" there were issued some important entomological papers.

Shortly after Say had begun in Philadelphia to give to the world the results of his researches, Thaddeus William Harris in the "New England Farmer" and the "Massachusetts Agricultural Repository" commenced to publish upon the Insects of Massachusetts, and continued until his death in 1856 to write instructively upon various insects injurious, or useful, and contributed a number of important papers of a descriptive and systematic nature to the literature. Harris was only second to Say as a pioneer in this field of inquiry, and his "List of the Insects of Massachusetts," published at Amherst by Professor Hitchcock in 1833, and his "Report on the Insects of Massachusetts Injurious to Vegetation" (which in an edition revised by Flint, is still a classic) greatly helped to develop an interest in economic entomology.

There were a few ardent and industrious students of entomology in the United States who labored during the half century preceding the Civil War besides those whom I have already mentioned. We owe gratitude to Melsheimer, Haldeman, Baron Osten Sacken, (the latter a member of the Russian Legation in Washington) and to Morris, as well as to Hagen, who was an importation from Europe, brought over by the elder Agassiz. Beside these there were a score or more of others, who were collecting, studying, classifying, preparing to give to the world the results of their labors, but belonging to a younger generation which was just about to appear upon the stage. They may be said to have been simply pluming their wings for flight at the end of the epoch of which I am speaking. They were triumphant in achievement at a later date, and a few, very few of them, survive to this day as the grizzled veterans of half a century ago. 
I can still very vividly recall the later years of the epoch of which I have been speaking, and no doubt a few of my hearers this evening, whose memories take them back to their early days in school and college "before the war," can do as much. As a boy I had become interested in the study of insects. The only works upon the subject to which I had access at the time were an original copy of Say's "American Entomology," Jaeger's "Life of North American Insects," and Boisduval and Leconte's "Histoire Générale des Lepidoptères de l'Amérique Septentrionale." These books were supplemented through the kindness of an obliging congressman by the Annual Report of the Smithsonian Institution for 1858, containing instructions for the collection of insects, which I liked better than my catechism, and subsequently by a copy of Morris' "Catalogue." This was the sum of literature accessible to me. When I went to college at Amherst it was with a feeling of eagerness, founded upon a conviction that the doors of knowledge would at last be opened to me. I had collected a multitude of specimens, many hundreds of species in all orders. Imagine my despair when I asked my most genial instructor, Professor Edward Hitchcock, for assistance and guidance in determining my insects, to have that hearty and bluff worthy say to me: "Holland, there is not a man in Amherst who knows the first thing about insects." Professor C. B. Adams, the great naturalist, who, I had been told, had sometimes rocked me in my cradle in my West Indian home, where he lived during his stay in Jamaica, was dead and gone; his Jamaican insects in the Appleton Cabinet had mostly been devoured by Dermestes; I could do nothing, and therefore promptly gave up entomology and devoted myself to chemistry, geology, and botany, for teaching which there was more ample provision made. It was not until years later that I came back with vigor to the love of my boyhood. Blake, Cresson, Strecker, Scudder, Leconte, Horn, Grote, Henshaw, and many others were hard at work at that time, but I knew it not. I came to know them all in later years. But at that time there was no one to guide me. There was no army of entomological enthusiasts such as is found in our society with its membership of hundreds. The science had few votaries. They lived apart; their work had barely begun to see the light; and I knew them not.

We now come to the second epoch. On March 12, 1861, the Entomological Society of Philadelphia was constituted, being 
the first entomological society formed in the New World. In 1867 its corporate name was changed to "The American Entomological Society." It published under its earlier name six volumes of Proceedings, and in 1867 began the publication of the "Transactions of the American Entomological Society," now numbering forty-five volumes. The activities of this important association led to emulation in other parts of the country. It was followed gradually by the organization of kindred societies in Cambridge, Brooklyn, New York City, Washington, and elsewhere. All of these associations began to publish sooner or later.

The economic importance of our science began to be more generally recognized. A very great influence was exerted in this connection by the labors of a young entomological enthusiast who had recently left his home in England and come to the city of St. Louis, where we are assembled this evening. At the early age of twenty-five years, in 1868, Charles Valentine Riley was made the State Entomologist of Missouri. He began the publication of his "Reports," continued until 1877. They are to this day most valuable. In 1878 he was put by the Government of the United States in charge of a Commission appointed to investigate the ravages of the Rocky Mountain Locust. Later he was transferred to the Bureau of Entomology in the Department of Agriculture in Washington. The successful administration of the Bureau from 1881-1894 was largely due to his initiative and to the fact that he had a genius for calling to his aid men of the greatest competence. His successor is our friend and fellowmember, Dr. L. O. Howard. Serus redeat in celum!

Among the men who were the cotemporaries of Riley, and even his predecessors, there should be mentioned Professor B. D. Walsh, and the late Dr. Asa Fitch, both of whom rendered distinguished services in the fields of pure and applied entomology. The labors of Walsh related to the insect-life of Illinois and the Mississippi Basin, Fitch dealt with the insects of the State of New York. The writings of both of these learned men are exceedingly valuable.

An impetus to the study of entomology in North America was not only given by the establishment of the Bureau of Entomology in Washington, but by the establishment of agricultural schools and colleges in the various states under the provisions of the "Morrill Land Grant Act," which was passed 
on July 2, 1862, and was later thrice amended. An impulse was also received from the subsequent foundation of experiment stations, most of them in connection with the Land-grant Colleges. There also took place throughout the country a quickening of interest in so-called "Nature-studies," which has become intensified with the lapse of years. Entomology has found its way into the curricula of a number of the higher institutions of learning, and to some extent obtains a foothold in the schools of elementary grade in a number of the States. The ease with which material for study can be obtained in this branch of science, the wide range of biological facts which are brought into view, as well as the curious structure and beauty of many insects, appeal to many minds. While our science has not as yet assumed the same prominence which is accorded to botany in the curricula of institutions of learning, it nevertheless cannot any longer be regarded as an unpopular study.

I have alluded to the important influence exerted by the governmental recognition of the economic importance of entomology as having had its influence in the development of the science, and the multiplication of students in its various branches, but we ought not to fail to remember how large is the debt which is owing to the labors of individuals, who had little or no support in their labors from the governments of the States or from that of the Nation. Many of the foremost laborers in the field had to depend entirely, both in the prosecution of their researches and in the publication of the results, upon what their own pocket-books could provide, or upon the scant assistance which was given them by the learned societies to which they happened to belong. We are under profound obligations to the self-denying and patient labors of such men as Philip R. Uhler, Samuel H. Scudder, Alpheus S. Packard, William H. Edwards, Henry Edwards, John L. LeConte, and Dr. George Horn, to mention only a few of the illustrious dead, who brought to their work magnificent intellectual power, profound learning, great experience, and unquenchable enthusiasm. I have personal knowledge of the great sacrifices made by these men in their efforts to pave the way for those who should come after them. At great cost without hope of reward they laid the foundations upon which we are still building. None of the men of whom I am speaking, unless it be Packard and Scudder, received even indirectly assistance from the public 
treasury. Two of Packard's great monographs were indirectly published at government expense; and Dr. Scudder's monumental work upon fossil insects and his indispensable "Nomenclator Zoologicus" were issued under governmental auspices. Otherwise these most prolific writers were compelled to depend upon their own resources or upon such help as could be derived from the learned societies, with which they were affiliated, or the serial journals, the pages of which were open to them. I recall in this connection the fact that the late William $\mathrm{H}$. Edwards being desirous to publish the third volume of his "Butterflies of North America," a very expensive undertaking, wrote to me saying that in order to secure the necessary funds he had determined to offer his entire collection to the Trustees of the British Museum, hoping that they might purchase it, as they had already purchased the collection of A. R. Grote, containing his types of the moths of North America. I forthwith wrote to him, proposing that I would assume the expense of publishing the third volume of his work, provided that the collection should be ultimately turned over to me. The offer was promptly accepted. I only mention the incident, because it throws light upon the difficulties under which some of the most important works at our command were brought into being by their authors. Dr. Scudder told me that his "Butterflies of New England" had involved a personal outlay on his part of nearly ten thousand dollars, and that he would deem himself fortunate if the sales ultimately should return to him the capital he had invested, not speaking of the time and labor he had expended. Many of the most important works we possess are due to individual initiative in their conception and execution. A very remarkable work of this sort, which it might have been the glory of a nation to produce, is the Biologia CentraliAmericana, which stands as a monument to the learning and the generosity of a wealthy Englishman, my friend, the late F. Ducane Godman. Parts of this colossal work were written by Americans, notably the Section dealing with the Diptera, which was produced by our lamented colleague, Professor S. W. Williston.

Proceeding to a somewhat closer review of entomological activity in North America during the past fifty years, it is seen that the number of periodicals accessible to entomologists, who may desire to publish their observations, has been greatly 
increased. In the year 1860 there were only five or six such journals; today there are about fifty. Of course not all of these are of equal importance and dignity. The day, however, is past when a student of entomology in North America need fear that his work, if of value and significance, need long languish in darkness, and fail to be made known to his fellow-laborers.

Another fact worthy of note is not merely the multiplication of learned societies to which I have already alluded, but of institutions for research and for the promotion of a knowledge of the natural sciences. In 1860 there were only half a dozen museums in the new world, and these were quite in their infancy. Today there are a multitude of museums, some of them well-housed, well-equipped, and well-supported, which are fit to become the ultimate repositories of important entomological collections, and there are a number of endowed institutions, which in a broad manner promote intensive studies in natural science.

In 1860 the number of men and women engaged in entomological pursuits in the United States and Canada were numbered by scores; today they are numbered by thousands.

In 1860 there was not a single manual dealing with the science issued from an American press. Packard's "Guide to the Study of Insects" was the first to appear, and it came out in 1869. Today there are a number of textbooks easily available, and the young man or woman who wishes to make a serious study of the subject is not forced to fall back, as we, their elders, were, upon the pages of European writers, such as Burmeister.

The literature needed by the specialist in 1860 was scanty. Today it has grown to be so enormous that complaint is being made. Our greatest need at the present time is condensation. Compact manuals covering the various branches of the science are called for. Hand-books, such as the botanists have provided, covering the various orders, should be prepared.

In speaking of the growth of the literature of our science in America, I have been interested in examining the lists of entomological publications furnished by the "Zoological Record." In the year 1864, when that journal first appeared, one hundred and forty-nine papers upon entomology are listed, only five of which are from the pens of North American writers. I am quite sure that the figures given for that year are incorrect. 
The learned editors did not have access to, or accidentally overlooked a number of papers, which in that twelvemonth were published by American students. But they also overlooked the writings of a number of authors in other lands. For purposes of statistical comparison we may accordingly accept their figures as approximately correct. It appears in consequence that only 3.3 per cent of the entomological literature of the year 1864 was American in its origin. The "Zoological Record" for 1913 lists 2967 papers upon entomology, which had fallen under the eyes of the compilers. Of these 627 , or more than 21 per cent, were written by Americans or Canadians. In 1916, owing to the war, the number of contributions to scientific literature fell off very greatly. Only 1821 papers upon entomological themes are listed by the "Zoological Record" for that year, 1146 less than in 1913. Of this total 557 were published by citizens of the United States and Canada, more than 30 per cent of the total number of titles. In view of the fact that the "Zoological Record" seldom takes account of any but papers having taxonomic import, and that the vast body of papers dealing with economic questions in the field of entomology are not recorded, save exceptionally, these figures have great significance as showing the wonderful increase which has taken place in entomological activities in North America during recent years. The output of literature in our science has been multiplied ten-fold among us in the past five decades.

Another evidence of progress is discovered when we examine into the lists of species known to occur in North America, comparing them with earlier lists, so far as such exist. Taking up the "Catalogue of the Described Lepidoptera of North America," prepared by the Rev. John G. Morris and issued by the Smithsonian Institution in May, 1860, we find that he enumerates for the whole continent from Labrador to Panama, only 328 diurnal lepidoptera, or butterflies, of which 225 belong to the region called Boreal America by some, or by others the Nearctic Region. The latest check-list, published by Barnes \& McDonough, enumerates 661 species of butterflies as occurring in Boreal America. There have thus been added to the faunal list 436 species, the number given by Morris having been approximately trebled in the past five decades. There is even a greater advance shown in the case of the Heterocera, or moths. 
Morris gives the number of species of moths credited to the North American continent, of which he had knowledge, as 1340, a large number of which belonged to the Neotropical Area. Barnes \& McDonough, restricting themselves to Boreal America, list 7834 species as belonging to our fauna. The number of species of Heterocera known to occur in Boreal America has therefore since 1860 increased at least seven-fold.

What I have stated as to the Lepidoptera is typical of what has taken place in the other orders. The earliest list of beetles was prepared by Melsheimer, who confined himself to those species, which he knew to occur in Pennsylvania. He catalogued 1363 species. Crotch's Check-List, published in 1873, enumerated 7450 species of beetles found north of the Rio Grande of Texas. The supplement to his List by Austin raised the number to 9704 in the year 1880 . The Revised List by Henshaw, with the Supplements, brought the total to 11,256 in the year 1895 . The Catalogue by C. W. Leng, which will appear shortly, is reported to bring the number of species known in this faunal area up to 18,547 species, exclusive of sub-species and varieties.

The writings upon the Diptera by Osten Sacken and others, which appeared about 1860 , yield upon examination a total of known species in this order of less than 1,000. The great Catalogue prepared by our distinguished colleague, Dr. J. M. Aldrich, issued in 1905, gives a total of species found on the continent from the highest north to Panama of 9350. Some of these species may not be valid, but most of them are, and the field has only been partially explored.

In all the other orders a similar increase in the number of known species has taken place, and where at the beginning of the epoch only a few hundreds of species at the most were listed, we now discover that there are thousands known.

To have prepared an approximately correct estimate of all the recorded species in all the orders ascertained to be found upon the soil of the United States and Canada is a labor for which I have not had the necessary time. It would have required the careful examination of hundreds of papers, and extensive use of my adding-machine. I venture the statement, however, that there are probably not far from 60,000 species known, or in process of being named and described. Not more than one-sixth of these were known to science fifty years ago. 
There has been prodigious activity along taxonomic lines displayed by students of the subject during the past five decades.

One of the most marked developments of the past halfcentury has been the growth of interest in the economic aspects. of entomology. I have alluded already to the work done by Harris, Walsh, Fitch, and Riley. These men have had an army of enthusiastic successors, among them some who have rivalled and even surpassed the most excellent labors of those I have just named. Most of them are still with us, including our Nestor, Dr. Stephen A. Forbes. An English entomologist of renown, speaking to me some time ago of certain entomological reports which he had received from the United States Department of Agriculture and from various Agricultural Experiment Stations, said: "We have nothing like this in the Old World. The United States and the several States are greatly in advance of the European nations in your application of science to the arts of the agriculturist. I marvel at what you are doing."

But it is not only in connection with agriculture that the entomologist has proved his worth, but also in the field of medicine, as you are well aware. The study of disease-bearing insects, and the ascertainment of methods of prophylaxis are fields in which American students of our science have achieved results, which must prove of inestimable service to coming generations. May I say a word in this connection concerning the splendid "Monograph of the Culicidæ" in four great quarto volumes, prepared by our colleague, Dr. L. O. Howard, and his associate, Messrs. H. G. Dyar, and F. Knab which has just been published by the Carnegie Institution of Washington. I have carefully examined it, and am sure that it is the best piece of work in our science which the Carnegie Institution has thus far been allowed the privilege of publishing. For years to come it will be the standard work of reference for students in this difficult field of investigation.

Another sphere in which there has been marvelous progress not only in our country, but throughout the world, is that of technique. I might spend hours in speaking of this, but must content myself with a few words only. There has been a wonderful advance and improvement in the instruments and methods of research. Take that familiar tool, the microscope, which we all must constantly use, how wonderfully has it been improved! We have in the Carnegie Museum a microscope 
which in 1736 was presented by Linnæus to his fellow-student and friend, Bernard Jussieu, when they were students in Paris: It is for that day a good instrument, and I can still see through it, but there is a gulf between it and the instruments we employ today as wide as that between a toy pop-gun and the French $75 \mathrm{~s}$, which roared forth victory on the European battle-front. Take such a simple commodity as insect-pins as an example of what the use of modern machinery can accomplish. Pins in the days of Linnæus were made by hand; they were costly; they were clumsy. For mounting the minuter forms the best Linnæus had were about as good as marlin-spikes. Take the thousand and one odds and ends of apparatus which we employ in our work, how marvelously have all these things been improved! Photography has come to our aid, and with its help we are able to get and keep records, which the fathers would not have dreamed to be possible. As I sat and listened yesterday and today to the fine papers which were being read, and which were being illustrated by magnificent projections with the help of the electric lantern, I could not help in thought contrasting the present with the past, and wondering whether you younger men appreciate the inheritance into which you, through the labors of others, have come.

The review I have made is necessarily brief. I cannot avoid thinking that it should awaken in us satisfaction. The great field which is ours has at least been partially conquered. There remains, however, a vast amount of work to be done; it is far from being exhausted. Of only comparatively few species are the life-histories thoroughly known; the phylogenetic relationships of various groups and species await investigation; no doubt there are thousands of species yet to be discovered and named; and, in spite of the fine work done by Scudder and by Cockerell in paleontology, there must be innumerable species of fossil insects to be found and described. Many questions in economic entomology still await solution. There is reason, therefore, for you younger men to regard the future with hope and pleasurable anticipation. I am sure from what I have seen during the sessions here that we have before us a future still more brilliant than the past has been.

In conclusion, in these times of strife and discord it is a pleasure to recall how fraternal have been the relationships which have been maintained by all workers in our special field 
of inquiry. I desire especially to emphasize the cordial relationships which have been maintained during all these years between students living south of the St. Lawrence with those living north of that river. One of the best of all the entomological journals on the Continent is the "Canadian Entomologist." As it is one of the oldest, so it is one of the best-sustained publications of its kind. "The Entomological Society of Ontario" is a splendid organization, in which most of the leading workers within the United States have felt it an honor to have membership. For all practical purposes the entomologists of British North America and of the United States form one united brotherhood. Behold how good and pleasant it is for us thus to dwell together in unity! May I not express the hope that the friendly relationship which has so long been maintained among us may remain indissoluble, and the same spirit which has prevailed between these two great bodies of workers in the New World may extend to all brotherhoods of other nations, and that through our scientific friendships we all may help to bring in the reign of universal peace, the thought of which is dominant among us, and is emphasized by the anniversary of the birth of The Prince of Peace, which we have just celebrated. 


\section{$2 \mathrm{BHL}$ Biodiversity Heritage Library}

Holland, W. J. 1920. "The Development of Entomology in North America." Annals of the Entomological Society of America 13, 1-15.

https://doi.org/10.1093/aesa/13.1.1.

View This Item Online: https://www.biodiversitylibrary.org/item/43848

DOI: https://doi.org/10.1093/aesa/13.1.1

Permalink: https://www.biodiversitylibrary.org/partpdf/193513

\section{Holding Institution}

Smithsonian Libraries

\section{Sponsored by}

Smithsonian

\section{Copyright \& Reuse}

Copyright Status: NOT_IN_COPYRIGHT

This document was created from content at the Biodiversity Heritage Library, the world's largest open access digital library for biodiversity literature and archives. Visit BHL at https://www.biodiversitylibrary.org. 